\title{
КУЛЬТУРНІ ПАМ'ЯТКИ ГАРНІЗОННОГО ХРАМУ СВ. АП. ПЕТРА І ПАВЛА (КОСТЕЛ ЄЗУЇТІВ) У ЛЬВОВІ: КАПЛИЦЯ СВ. БЕНЕДИКТА
}

\author{
олег Друздєв \\ Місія «Центр Військового капеланства» ЛА УГКЦ (Львів, Україна) \\ e-mail: oleg.druzdev@gmail.com \\ ORCID: https://orcid.org/0000-0002-2110-8948
}

\begin{abstract}
У статті розкрито історію появи та функціонування каплиці святого Бенедикта у львівському костелі о. Єзуїтів. Проаналізовано зв'язки фундатора каплиці з львівським осередком Товариства Ісуса, а також причини появи нової святині у храмі та значення, яке вона мала для жителів Львова у різний час. На основі виявлених документів, зроблена теоретична реконструкція вигляду каплиці після їі відновлення у кінці ХІХ ст. Введено до наукового обігу два раніше невідомих документи з історії каплиці. Проаналізовано ідейне навантаження збережених до наших днів пам'яток, які збереглись у приміщенні колишнього костелу о. Єзуїтів.
\end{abstract}

Ключові слова: костел єзуїтів, єзуїти, Гарнізонний храм, святий Бенедикт-мученик, Дідушицькі, Замойські, Яблоновські

Відкриття у 2011 р. колишнього костелу єзуїтів у Львові, який отримав статус Гарнізонного храму міста, зумовив необхідність дослідження й осмислення його культурно-релігійної спадщини, вагомою частиною якої була каплиця святого Бенедикта-мученика. На жаль, в силу різних обставин, приміщення самої каплиці не дійшло до наших днів. Зараз про неї нагадує лише декор входу до неї, який зберігся у правій наві храму, надпрестольне зображення святого, знайдене на еморах церкви при відкритті та медальйон зі сценою передачі реліквій св. Бенедикта фундатору каплиці Єжи-Станіславу Дідушицькому. 3 огляду на статус храму у XVII-XVIII ст., поява нової каплиці в архітектурі та релігійному житті костелу є невипадковою та потребує вивчення. Зокрема, у розрізі ролі культу св. Бенедикта у соціокультурному просторі міста сер. XVIII ст. Сьогодні ж, вивчення історії каплиці та практик вшановування святого має практичне значення з огляду на процес відновлення храму, який триває з 2012 р. Зважаючи на це, пропонована у заголовку тема $є$ актуальною та вартою дослідницької уваги.

Джерельний комплекс даної теми є недосліджений. На сьогоднішній день відомий лише один опублікований інвентар, який стосується періоду перебування реліквій святого у каплиці палацу родини Дідушицьких у Цуцуловичах (зараз с. Вільхівці Жидачівського району Львівської області) ${ }^{1}$. Інші документи невідомі/не введені до наукового обігу в зв'язку з розпорошеністю архіву львівського осередку Товариства Ісуса (далі - TI). Незважаючи на це, вдалося віднайти у фондових колекціях Центрального державного історичного архіву у Львові (далі ЦДІАЛ) два інвентарі каплиці св. Бенедикта, які можна датувати другою полови-

\footnotetext{
1 Betley A., Markiewicz A. Pałac w Cucułowcach w świetle inwentarza pośmiernego Jerzego Stanisława Dzieduszyckiego z 1731 roku. Kraków, 2016. S. 47-166.
} 
ною XVIII ст. ${ }^{2}$ Саме вони й стали основним джерелом для написання цієї статті. Важливим елементом дослідження є матеріали, які стосуються періоду відновлення каплиці у кінці XIX ст. після її ліквідації століттям раніше. Мова йде про документ, який стосується реставрації каплиці з архіву родини Дідушицьких, що знаходиться у фондових колекціях Львівської національної наукової бібліотеки імені Василя Стефаника 3 . Очевидно, що даних матеріалів $є$ замало для повноцінного висвітлення історії каплиці. Водночас, отримана інформація дає можливість сформувати певне уявлення про цю святиню, її вигляд і значення для історії храму, що й є предметом нашої статті.

Історіографія даної теми доволі невелика. Перша праця про каплицю була видана в 1753 р. у Львові та мала назву «Відомості про обставини мученицької смерті святого Бенедикта в Римі» ${ }^{4}$. На жаль, для українського дослідника ця праця є малодоступною з огляду на ї̈ відсутність в архівах/бібліотеках України. Після цієї роботи настав період понад столітнього «мовчання», який можна пояснити скасуванням Товариства Ісуса та ліквідацією австрійською владою самої каплиці. На зміну такій ситуації прийшла достатньо велика активність дослідників, які жили у середині XIX ст. Хронологічно першою працею, яку слід згадати, $є$ робота єзуїта о. Каспера Несецького TI, яка була написана ще у середині XVIII ст., однак видана лише у 1845 р.5. Вона не стосувалась безпосереднього ні львівського костелу єзуїтів, ні тим паче каплиці св. Бенедикта, однак автор згадав про неї у контексті опису життя Маріанни Дідушицької6.

Наступною працею, яка подає вже більші відомості, у першу чергу про фундаторів святині, є стаття Феліціана Лобеського «Пам'ятник Єжи і Маріанни з Замойських Дідушицьких в костелі Єзуїтів»7. Вагома практична цінність цієї публікації полягає у поданні автором перекладу епітафії фундаторів каплиці. Розповідаючи про засновників святині, очевидно, слід згадати й про «Родинна хроніка Дідушицьких», авторства Мауриція Дідушицького ${ }^{8}$ У ній автор, через призму біографії ЄжиСтаніслава Дідушицького, подає деякі відомості про мощі святого Бенедикта, періоду їх перебування у Цуцулівцях і перенесення до львівського храму єзуїтів.

Припускаємо, що базуючись на даних «Хроніки», згадував про каплицю й один 3 чільних класиків «єзуїтського» історіописання - о. Станіслав Заленський ТІ. У своїх працях, зокрема, мова йде про другу частину п'ятого тому «Єзуїти в Польщі»9, а також такі роботи як «Отці Єзуїти у Львові» 10 та «Костел святих апостолів Петра і Па-

\footnotetext{
2 Центральний державний історичний архів України у м. Львові (далі - ЦДІАЛ). Ф.52. Оп. 1. Спр. 234. Арк. 272-275.

3 Львівська національна наукова бібліотека України імені В.Стефаника (далі - ЛннБУ імені В. Стефаника). Відділ рукописів. Ф. 45. Оп. 3. Спр. 1947. Арк. 1-3.

4 Dzieduszycki M. Kronika domowa Dzieduszyckich: Obbita w dwustu exemplarzach nakladem familii dła własnego uzytku. Lwów, 1865. S. 149.

${ }^{5}$ Herbarz polski Kaspra Niesieckiego S.J.: powiększony dodatkami z poźniejszych autorów, rękopismów, dowodów urzędowych. Lipsk, 1845. T. 8. 652 s.

6 Ibid. S. 71.

7 Łobieski F. Pomnik Jerzego i Maryanny z Zamojskich Dzieduszyckich w kościołe Jezuitów // Dodatek tygodniowy przy Gazecie Lwowskiej. 1856. № 37. S. 153-154.

8 Dzieduszycki M. Kronika domowa Dzieduszyckich...

9 Załęski S. Jezuici w Polsce. Kolegia i domy założone w pierwszej dobie rządów Zygmunta III 1588-1608.

T. IV. Cz. 2. Kraków: drukiem i nakładem Drukarni W. Lanczyca i sp. 1904. 1019 s.

10 Załęski S. 00. Jezuici we Lwowie. Lwów, 1880. 118 s.
} 
вла о. єзуїтів у Львові»11, автор вперше описує історію святині у контексті життя самого храму. Важливими є відомості, які стосуються періоду кінця ХІХ ст., коли постало питання відновлення приміщення каплиці. Однак, найважливішим у студіях о. Станіслава Заленського $є$ власне контекст цілісного розвитку храму, частиною якого була каплиця св. Бенедикта.

Крім о. Заленського, слід згадати й іншого єзуїтського історика початку XX ст. о. Яна Сиганського. Його праця безпосереднього не стосувалася предмету наших студій. Однак, варто зауважити, що у контексті добудови приміщення каплиці, о. Сиганський описує значні перебудови у самому храмі, який раніше, на його погляд, мав лише одну наву та вісім бокових каплиць ${ }^{12}$. Цим самим він розпочав доволі довгу дискусію, яку можна вважати завершеною у наш час, коли документально було доведено, що храм одразу будувався як тринавовий, а добудова каплиці не вплинула на загальну конструкцію костелу ${ }^{13}$.

Парадоксально, та після своєрідного сплеску дослідницької активності кінця XIX - поч. XX ст. настала майже столітня тиша. Порушили її на початку XXI ст. польські дослідники, серед яких слід згадати професорів Казімєжа Карольчака, Ришарда Моньчинського й Анджея Бетлея. Варто зазначити, що кожен з цих дослідників підійшов до теми каплиці св. Бенедикта виходячи зі своїх дослідницьких зацікавлень, не приділяючи їй окремих студій. Професор Казімєж Карольчак зосередив свою увагу на родині Дідушицьких, відповідно інформація про реліквії св. Бенедикта подається лише побічно ${ }^{14}$.

Більш предметною є праця проф. Ришарда Моньчинського ${ }^{15}$, який більше уваги присвятив самим мощам та їх почитанню. Найбільш вагомими працями для нашої роботи є студії проф. Анджея Бетлея. Серед масиву напрацювань автора, зокрема тих, які стосуються історії оздоблення костелу о. єзуїтів, можемо виділити роботу «Палац в Цуцулівцях у світлі посмертного інвентаря Єжи-Станіслава Дідушицького з 1731 р.»16, видану в 2016 р. у співавторстві з Анною Маркевич. Праця важлива кількома моментами. Найперше, написана вона на основі документу збереженого у ЦДІАЛ. Це важливо з точки зору актуальності та подальших джерельних пошуків для українських дослідників. Крім цього, з огляду на важливість реліквій св. Бенедикта у структурі палацу в Цуцулівцях, подано достатньо інформативні дані про передісторію цих мощей та їх шлях до львівського костелу о. єзуїтів.

Загалом, аналізуючи доробок дослідників, можемо зауважити достатньо значну нестачу інформації про каплицю св. Бенедикта, яка відігравала значну роль у релігійному житті колишнього костелу єзуїтів у Львові.

Фундація каплиці св. Бенедикта у львівському храмі Товариства Ісуса безпосередньо пов'язана з постаттю Єжи-Станіслава Дідушицького. Син подільського воєводи Франциска Дідушицького та Софії Яблоновської гербу Прус III, великий конюший коронний, ловчий великий коронний і староста жидачівський Єжи-

\footnotetext{
11 Załęski S. Kościół oo. jezuitów we Lwowie pod wezwaniem ss. Apostołów Piotra i Pawła. Lwów, 1897. $35 \mathrm{~s}$.

12 Sygański J. Święty Stanisław Kostka. Patron Lwowa. Lwów, 1906.

13 Paszenda J. Kosciół jezuitów we Lwowie w świetle żródeł archiwalnych. Budowle jezuickie w Polsce. T. 2. Kraków, 2000.

${ }^{14}$ Karolczak K. Dzieduszyccy: dzieje rodu: linia poturzycko-zarzecka. Kraków, 2001.

15 Mączyński R. Nowożytne konfesje polskie. Artystyczne fory gloryfikacji grobów świętych i błogosławionych w dawnej Rzeczypospolitej. Toruń, 2003.

16 Betley A., Markiewicz A. Pałac w Cucułowcach...
} 
Станіслав все життя був пов'язаний з місцевими єзуїтами. Найперше через родину, яка з середини XVII ст. активно підтримувала львівський осередок TI. Мова йде, зокрема, про його матір Софію, яка була донькою мечника коронного ЯнаСтаніслава Яблоновського, котрий підтримував тісні зв'язки з єзуїтами та був по смерті похований у криптах їх львівського костелу. У цих же монахів навчався й брат Софії - гетьман Станіслав-Ян Яблоновський, а згодом і його діти.

Зважаючи на активну фінансову допомогу єзуїтам зі сторони родини Яблоновських, вже станом на поч. XVIII ст. у криптах костелу з'явилась їхня родинна усипальниця, в якій знайшли спочинок і батьки Єжи-Станіслава. У такий спосіб храм поступово перетворювався на своєрідний родинний мавзолей родин Яблоновських і Дідушицьких ${ }^{17}$. Це, очевидно, відіграло значну роль при формуванні заповіту ЄжиСтаніславом, про що ми ще згадаємо далі. Іншим, теж важливим чинником, який безумовно впливав на взаємини між ним та єзуїтами, був факт навчання Дідушицького у львівській колегії, а згодом у французькому коледжі Людовіка Великого, який теж був заснований Товариством Ісуса. Зважаючи на вищесказане, не дивним $€$ той факт, що капеланом своєї сім'ї Єжи обрав теж єзуїта - о. Ігнатія Деламарса TI18. 3 огляду на це, цілком логічним видається факт чималих дарувань львівським єзуїтам, які знайшли своє відображення у заповіті Дідушицького. Згідно нього, колегії перейшло багато що з мистецької та книжкової колекції шляхтича, а також головна святиня родинного маєтку в Цуцулівцях - мощі св. Бенедикта-мученика.

Дані реліквії були привезені Дідушицьким з Риму, де він перебував у якості посла короля Августа II до Папи Римського Інокентія XII, який ці мощі йому й подарував ${ }^{19} .3$ «Хроніки» дізнаємось, що у 1698 р. Єжи-Станіслав отримав реліквії, «принесені $з$ цвинтаря св. Калліста, а саме цілі кості та ампулка крові св. Бенедиктамученика з перших християнських віків» 20 . Автентичність цих мощей було підтверджено окремим документом за підписом кардинала Франциска Барберіні. Судячи із зображення святого, яке збереглося до наших днів у колишньому костелі єзуїтів (тепер Гарнізонний храм св. ап. Петра і Павла), Бенедикт був римським військовим. Жив орієнтовно у II-III ст. н.е. і з огляду на приставку «мученик» помер насильницькою смертю у Римі. Припускаємо, що жити майбутній святий міг у часі правління імператорів з династії Северів (кін. II - поч. III ст. н.е.) під час якого у Римі відбувалося переслідування християн. Однак, це твердження потребує ще більш детального вивчення.

Щодо перенесення реліквій до храму о.єзуїтів, то це питання вирішувалось у перші роки по смерті Єжи-Станіслава. Відомо, що станом на 1734 р. до колегії вже було перенесено його книгозбірню, яка того ж року згоріла під час пожежі 21 . Пошкодження, яких зазнав храм, були достатньо серйозними, тому питання зі створенням окремого місця для мощей св. Бенедикта було відкладене. Водночас припускаємо, що відновлення костелу відбувалось з урахуванням появи нової каплиці. Про це свідчить відносно швидка побудова каплиці, яку дружина Єжи-Станіслава -

\footnotetext{
17 Betley A. Epitafia w kościele Jezuitów we Lwowie // Fides Ars Scientia - Studia dedykowane pamięci Księdza Kanonika Augustyna Mednisa, Tarnów, 2008.

${ }^{18}$ Lisiecka E., Zdeb K. Koniuszyna Wielka Koronna. 2017. URL: http://przewodnicyzamosc.pl /archiwa/5528

${ }^{19}$ Karolczak K. Dzieduszyccy: dzieje rodu: linia poturzycko-zarzecka... S. 28.

20 Dzieduszycki M. Kronika domowa Dzieduszyckich... S. 149.

${ }^{21}$ Dzieduszycki M. Jerzy Dzieduszycki. Koniuszy Wielky koronny, Starosta żydaczowski // Dodatek tygodniowy przy Gazecie Lwowskiej. 1860. № 31. S. 122.
} 
Маріанна з Замойських «з фундаментів вбудувана»22. Урочисте внесення реліквій св. Бенедикта до храму відбулося 28 травня 1738 р. (при тому, що відбудова церкви завершилась лише 1739 р.23) з властивими для цього часу урочистими декораціями самого костелу та процесією на центральній площі міста24.

Збережені інвентарі з XVIII ст. дають підстави говорити про багату оздобу каплиці25. Очевидно, що основою декору стали цінності привезені з Цуцулівців. Це можна побачити, зіставивши інвентарі обох каплиць 26. Багата оздоба, у певному сенсі, підкреслювала статус реліквій. Як вважає професор А. Бетлей, перенесення мощей святого мало на меті створення своєрідного мавзолею римського мученика27. Така пошана, звісно, не випадкова. У 1724 р. папа Інокентій XIII надав право відпусту в день пам'яті святого, якого вшановували у кожну першу неділю після 16 липня 28 . Цей привілей був наданий у зв'язку зі зростаючим вшановуванням культу св. Бенедикта, за заступництвом якого люди отримували зцілення у часі епідемії 1716 р. ${ }^{29}$ Відповідно, отримавши ці реліквії, храм оо. єзуїтів у Львові ставав місцем відпусту, що, очевидно, сприяло підвищенню авторитету місцевого осередку TI.

Новозбудована каплиця була, порівняно з існуючими у храмі, достатньо великою. Крім самого вівтаря з реліквіями святого, було ще два - вівтар із зображенням Ісуса Христа та вівтар Богородиці ${ }^{30}$. Будівля мала купол, який примикав до південної стіни храму 31 . Вікна каплиці виходили у двір колегіуму, відповідно вірянам потрапити до неї можна було лише зі сторони храму. Разом з цим, порівнюючи з каплицею у Цуцулівцях, каплиця у костелі єзуїтів була меншою. Про це можна судити хоча б з відсутності амвону та малого органу, які були в часі перебування реліквій у родинному маєтку Дідушицьких ${ }^{32}$. Відомо, що первинний проект не врахував питання водовідведення, тому мури будівлі нищила волога 33.3 огляду на це, у 1745 р. було зміцнено фундаменти каплиці і, що не менш важливо, добудовано крипти ${ }^{34}$.

Факт добудови усипальниці засвідчив бачення каплиці як своєрідного мавзолею сім'ї Єжи-Станіслава та Маріанни Дідушицьких. На користь думки про «персональний мавзолей» свідчить те, що нащадків ця сім'я не мала, батьки ЄжиСтаніслава були поховані в іншій крипті у тому ж костелі. Відповідно, крипта могла плануватись лише для фундаторів каплиці. Ще одним підтвердженням цієї тези $€$ поява, по смерті Маріанни у 1751 р. навпроти входу до каплиці, пам'ятної епітафії

\footnotetext{
22 Herbarz polski Kaspra Niesieckiego S.J.: powiększony dodatkami z poźniejszych autorów, rękopismów, dowodów urzędowych. T. 8. Lipsk, 1845. S. 71.

23 Łuszczak G. Nauczyciele i wychowawcy szkól jezuickich we Lwowie 1608-1773. Kraków, 2010. S. 14.

${ }^{24}$ Betley A. Oprawy artystyczne uroczystości okazyjonalnych we Lwowie w XVIII wieku: proba rekonesansu // Velis quod possis: studia z historii sztuki ofiarowane profesorowi Janowi Ostrowskiemu. Kraków, 2016. S. 62.

25 ЦДІАЛ. Ф. 52. Оп. 1. Спр. 234. Арк. 272-275.

26 Betley A., Markiewicz A. Pałac w Cucułowcach... S. 47-166.

27 Betley A. Oprawy artystyczne uroczystości okazyjonalnych we Lwowie w XVIII wieku... S. 61.

28 Dzieduszycki M. Kronika domowa Dzieduszyckich... S. 190.

${ }^{29}$ Dzieduszycki M. Jerzy Dzieduszycki. Koniuszy Wielky koronny, Starosta żydaczowski // Dodatek tygodniowy przy Gazecie Lwowskiej. 1860. № 30. S. 118.

30 ЦДІАЛ. Ф. 52. Оп. 1. Спр. 234. Арк. 274-275.

31 Betley A., Markiewicz A. Pałac w Cucułowcach... S. 24.

32 Ibid. S. 12.

33 Załęski S. Kościół oo. jezuitów we Lwowie pod wezwaniem ss. Apostołów Piotra i Pawła... S. 15.

34 Betley A., Markiewicz A. Pałac w Cucułowcach... S. 22.
} 
Єжи-Станіслава та Маріанни Дідушицьких 35 . Така форма увіковічення цілком вписувалась у загальну картину «родинної пам'яті» у костелі єзуїтів. У лівій наві храму протягом XVIII ст. формувався цілий комплекс епітафій родини Яблоновських 3 якими були породичені фундатори каплиці св. Бенедикта36. Тому поява нової святині в храмі одночасно підвищувала престиж храму, який ставав місцем відпусту та реалізовувала доволі класичний варіант увіковічення пам'яті окремих шляхетських родин.

Очевидно, багата оздоба каплиці супроводжувалася відповідним фінансовим забезпеченням ії існування. Зокрема, на вівтар св. Бенедикта було записано 31000 флоринів, на вівтар Богородиці - 19000 , окремо був запис для братства, яке діяло при каплиці - 2 000. Сумарно, судячи з інвентарю XVIII ст., можемо говорити про суму в 52000 флоринів, яку записала на каплицю лише фундаторка ${ }^{37}$. Варто зауважити, що станом на XVIII ст. каплиця св. Бенедикта була достатньо активною частиною духовного життя міста. Зокрема відомо, що 9 квітня відзначалось свято Богородиці Страждальної. Святкова Меса відбувалася у каплиці за участі католицьких єпископів руського та вірменського обрядів ${ }^{38}$. Слід згадати, що поява нової ікони Богородиці Страждальної у Львові навіть викликала конфлікт між єзуїтами та францисканцями, які теж мали таку ікону. Цю суперечку виграли єзуїти у 1744 p. ${ }^{39}$

Скасування Товариства Ісуса у 1773 р. внесло свої корективи. Вже в кінці XVIII ст. каплиця була ліквідована. Вівтар з реліквіями святого було поміщено на місці вхідних дверей до каплиці, приміщення якої було розділено на дві частини. В одній знаходився архів судових актів, в іншій - приміщення для возного 40 . Крипти були ліквідовані, останки фундаторів вивезені на цвинтар. Їх подальша доля невідома. Територія усипальниці віддана під складське приміщення ${ }^{41}$. Оздоба каплиці була реквізована австрійською владою. Згідно даних о. Станіслава Заленського, коштовності було переплавлено на гроші42. Доля інших предметів декорації не встановлена. Припускаємо, що як і у випадку з рештою оздоби самого храму, ці речі могли роздати іншим костелам, або ж передати у власність капітули.

3 ліквідацією Товариства Ісуса, культ св. Бенедикта поступово став занепадати. Очевидно, пік його популярності припав власне на сер. XVIII ст. і був пов'язаний з уявленням про заступництво святого у часи епідемій. Згодом, центральним моментом пошанування реліквій був факт отримання відпусту в день пам'яті святого. Свідченням невисокого рівня вшанування культу є відсутність спроб повернення каплиці храму протягом майже всього XIX ст. Ситуація змінилась у кінці XIX ст. і пов'язано це з ініціативою Мауриція Дідушицького. Варто зауважити, що ця ідея зустріла спротив глави роду графа Володимира Дідушицького ${ }^{43}$. Однак, це не зава-

\footnotetext{
35 Łobieski F. Pomnik Jerzego i Maryanny z Zamojskich Dzieduszyckich w kościołeJezuitów... S. 154.

36 Betley A. Epitafia w kościele Jezuitów we Lwowie... S. 216.

37 ЦДІАЛ. Ф. 52. Оп. 1. Спр. 234. Арк. 272.

38 Załęski S. Kościół oo. jezuitów we Lwowie pod wezwaniem ss. Apostołów Piotra i Pawła... S. 22.

39 Załęski S. 00. Jezuici we Lwowie... S. 22.

40 Załęski S. Jezuici w Polsce... T. IV, Cz. 2. S. 908.

${ }^{41}$ Karolczak K. Dzieduszyckich związki ze Lwowem // Lwów: miasto, społeczeństwo, kultura: studia z dziejów Lwowa. T. 2 / pod red. Henryka W. Żalińskiego i Kazimierza Karolczaka. Kraków: Wydawnictwo Naukowe Wyższej Szkoły Pedagogicznej, 1998. S. 79.

${ }^{42}$ Załęski S. O0. Jezuici we Lwowie... S. 16.

43 Załęski S. Jezuici w Polsce... T. IV. Cz. 2. S. 908.
} 
дило вже Августу Дідушицькому (сину Мауриція) від імені роду направити супліку австрійському цісарю у справі повернення приміщення каплиці.

3 огляду на особисті взаємини між урядовими структурами, які знаходились 3 кінця XVIII ст. у приміщенні колишнього колегіуму єзуїтів, і родиною Дідушицьких, справа тягнулася досить довго. Вирішенням проблеми стало втручання суперіора єзуїтів о. Пйотра Бапста, який запевнив уряд, що каплиця буде передана у власність храму, а не родини Дідушицьких. Вартою уваги є аргументація для чого храму ще одне приміщення. Зокрема, суперіор наголошував, що відновлення каплиці не принесе шкоди державній інституції, якій ця територія непотрібна, водночас у храмі ця каплиця створить додаткові місця для вірян під час Мес, а також у новому приміщенні буде створено умови для сповідання хворих і глухих ${ }^{44}$. Результатом спільних зусиль родини Дідушицьких і суперіора єзуїтів став указ цісаря про повернення приміщення колишньої каплиці св. Бенедикта храму 2 липня 1892 р.

В якому вигляді існувала каплиця з кінця ХІХ ст. до 1910 р. судити важко. Ймовірно, за умови відсутності грунтовних перебудов приміщення у XIX ст., в загальних рисах конструкція каплиці не змінювалася з XVIII ст. Прикметно, що незважаючи на запевнення суперіора, що родина Дідушицьких не отримає цю каплицю у власність, де-факто, саме вона нею й опікувалась. Саме тому, поряд з оригінальною назвою часто вживається термін «каплиця Дідушицьких»45. Властиво, саме коштом цієї родини було проведено реставрацію у 1910 р.

Важливим джерелом до цієї події є кошторис реставрації разом із замітками реставратора, який зберігається у фондах Львівської національної наукової бібліотеки ім. Василя Стефаника ${ }^{46}$. Документ укладений керівником робіт, архітектором Державної промислової школи, професором Діонізієм Кричковським 22 грудня 1909 р., очевидно на замовлення Дідушицьких, які оплачували роботи ${ }^{47}$. Згідно кошторису передбачалося відновлення вхідного порталу, стін, переміщення вівтаря з північно-західної сторони на північно-східну тощо 48 .

Водночас, судячи з критичних заміток реставратора, які супроводжують кошторис, можемо припустити, що план реставрації був складений згідно побажань родини і багато у чому змінював первинну конструкцію каплиці. Так, зокрема, Д. Кричковський висловлював незадоволення ідеєю зміни розташування вівтаря, оскільки «при відправі Літургії, священник має багато світла від двох вікон, які зараз $є$; розміщення лавок зараз $є$ вигіднішим, ніж якби вівтар був розміщений при лівій стороні каплиці як зазначено в плані...» ${ }^{49}$. Також автор висловлював зауваги щодо ідеї розширення віконних порталів, що передбачало «розбирання старих, грубих мурів»50, ідеї розміщення гербу Сас родини Дідушицьких над входом до каплиці та щодо збереження існуючих розписів, які він трактував як «дуже бридкі і навіть невідповідні для святого місця». Варто згадати про пропозицію реставратора перенести епітафію Єжи-Станіслава та Маріанни до самої каплиці, яку, однак, не було підтримано. На жаль, важко встановити наскільки цих зауваг було дотрима-

\footnotetext{
44 Ibidem.

45 Karolczak K. Dzieduszyckich związki ze Lwowem... S. 81.

46 ЛННБУ імені Василя Стефаника. Відділ рукописів. Ф. 45. Оп. З. Спр. 1947. Арк. 3.

${ }^{47}$ Sprawozdania Grona c.k. Konserwatorów i Korespondentów Galicyi Wschodniej. T. III, Nr. 88-89. Lwów, 1910. S. 12.

48 ЛННБУ імені Василя Стефаника. Відділ рукописів. Ф. 45. Оп. 3. Спр. 1947. Арк. 1.

49 Ibid. Арк. 2.

50 Ibidem.
} 
но. Відомо, що згідно рішення родини, у каплиці було встановлено пам'ятні таблиці на честь Мауриція, Володимира та Войцеха Дідушицьких. Також коштом Анни Волянської та Софії Волковіцької (обоє з роду Дідушицьких) було встановлено нові вітражі й образ Ченстоховської Богородиці.

Про подальше функціонування каплиці, за відсутністю джерел, судити важко. Відомі плани з обмірами приміщення храму та колегії з 1939 р. Згідно них каплиця мала розміри 10,5×7,8 м (довжина на ширину) ${ }^{51}$. Припускаємо, що такі ж розміри вона мала й у попередні періоди, з огляду на відсутність даних про масштабні перебудови. Після закриття храму радянською владою 4 червня 1946 р., каплиця була ліквідована. Мощі св. Бенедикта, разом з іконою Богородиці Страждальної, вивезені до Польщі і знаходяться у Кракові.

3 відкриттям у 2011 р. приміщення костелу в якості Гарнізонного храму, постало питання про реставрацію збережених предметів культури. Нажаль, на сьогоднішній день про каплицю св. Бенедикта нагадують лише вхідний портал зі стюкковою декорацією, виконаною у 1741-45 рр., епітафія фундаторів, виконана у 1753 p.52 та таблиця зі сценою передання реліквій святого Єжи-Станіславу Дідушицькому, яку в XX ст. перенесли із захристії костелу до каплиці св. Станіслава Костки ${ }^{53}$.

Окремо слід згадати про полотно із зображенням святого, орієнтовно XVIII ст., яке було віднайдене на емпорах храму при відкритті і раніше використовувалось, очевидно, в якості надпрестольного зображення у головному вівтарі храму в день пам'яті святого. Такий висновок можна зробити виходячи з: 1. Відсутності даного зображення в інвентарних описах каплиці; 2. Розмірів полотна та використання аналогічних зображень у дні пам'яті інших святих. Зокрема, відоме фото полотна із зображенням сцени смерті бл. Анджея Боболі, виставлене у костелі в травні 1907 р. Крімцього, слід згадати про вищезгадану таблицю зі сценою передання мощей святого. Справа в тому, що у колишній каплиці св. Станіслава Косткиця таблиця знаходиться поруч з іншою, на якій зображено св. Маргариту Алякок, яка була засновницею культу Святого Серця Ісуса. Цей культ, починаючи з XVIII ст., активно пропагували самі єзуїти. Відповідно, помістивши ці два зображення поруч, монахи підкреслили важливість почитання як Святого Серця Ісуса, так і реліквій св. Бенедикта.

Висновки. Період XVIII ст. для багатьох храмів середмістя Львова став часом модернізації. Відповідно, в умовах своєрідної конкуренції за престиж, а відтак і за парафіян, Товариство Ісуса потребувало своєї «відповіді» на розвиток інших орденів у місті. Нею стало оновлення храму після пожежі 1734 р., у рамках якого було відкрито багато оздоблену каплицю св. Бенедикта-мученика фундації вихованця єзуїтів Єжи-Станіслава Дідушицького. Важливим моментом формування культу святого став факт дарування цих реліквій Папою Римським, а також надання ним відпусту в день пам'яті святого, що автоматично перетворювало храм на відпустове місце. Це, у свою чергу, сприяло зростанню авторитету костелу. Також, слід згадати, що відпуст був наданий через заступництво святого у період епідемій, що теж було важливим для періоду XVIII ст.

\footnotetext{
${ }^{51}$ Betley A. Kościół p. w. ŚŚ. Piotra i Pawła oraz dawne kolegium ks. Jezuitów // Materiały do dziejów sztuki sakralnej na ziemiach wschodnich dawnej Rzeczypospolitej / red. J.K. Ostrowski. Cz. 1: Kościoły i klasztory Lwowa z okresu przedrozbiorowego. T. 20. Kraków, 2012.

52 Betley A. Epitafia w kościele Jezuitów we Lwowie... S. 216.

53 Łobieski F. Pomnik Jerzego i Maryanny z Zamojskich Dzieduszyckich w kościołe Jezuitów... S. 154.
} 
Водночас, не можна вважати культ св. Бенедикта популярним серед львів'ян XIX-XX ст. Свідченням цього є ліквідація каплиці в кінці XVIII ст. і повільний процес iї повернення у кінці XIX ст. Очевидно, зі святинею, яка мала б велике значення для духовного життя міщан, було би вчинено в інший спосіб. Прикметно, що після відновлення каплиці, її трактували швидше як родову власність Дідушицьких, ніж велику святиню для львів'ян. Свідченням цього $є$ припинення існування культу святого після Другої світової війни. Його мощі були вивезені до Польщі, де покояться у криптах храму Пресвятого Серця Ісусового у Кракові. Незважаючи на це, каплиця св. Бенедикта $є$ вагомою сторінкою історії духовності львів'ян і місцевого костелу єзуїтів.

\section{REFERENCES}

Betley, A. (2016). Oprawy artystyczne uroczystości okazyjonalnych we Lwowie w XVIII wieku: proba rekonesansu. In Velis quod possis: studia $z$ historii sztuki ofiarowane profesorowi Janowi Ostrowskiemu. Kraków: Societas Vistulana [in Polish].

Betley, A. (2008). Epitafia w kościele Jezuitów we Lwowie. In Fides Ars Scientia - Studia dedykowane pamięci Księdza Kanonika Augustyna Mednisa. Tarnów: Muzeum Okręgowe w Tarnowie [in Polish].

Betley, A. (2012). Kościół p.w. ŚŚ. Piotra i Pawła oraz dawne kolegium ks. Jezuitów. In Ostrowski, J.K. (Ed.). Materiały do dziejów sztuki sakralnej na ziemiach wschodnich dawnej Rzeczypospolitej. Cz. 1: Kościoły i klasztory Lwowa z okresu przedrozbiorowego. T. 20. Kraków: Wydawnictwo Antyka [in Polish].

Betley, A. \& Markiewicz, A. (2016). Pałac w Cucułowcach w świetle inwentarza pośmiernego Jerzego Stanisława Dzieduszyckiego z 1731 roku. Kraków: Wydawnictwo Attyka Kraków [in Polish].

Dzieduszycki, M. (1860). Jerzy Dzieduszycki. Koniuszy Wielky koronny, Starosta żydaczowski (Dodatek tygodniowy przy Gazecie Lwowskiej, № 31) [in Polish].

Dzieduszycki, M. (1860). Jerzy Dzieduszycki. Koniuszy Wielky koronny, Starosta żydaczowski (Dodatek tygodniowy przy Gazecie Lwowskiej, № 30) [in Polish].

Dzieduszycki, M. (1865). KronikadomowaDzieduszyckich: Obbita $w$ dwustu exemplarzach nakladem familii dła własnego uzytku. Lwów: Z Drukarni Z.N. Ossolińskich [in Polish].

Niesiecki, Kasper (1845). Herbarz polski Kaspra Niesieckiego S. J.: powiększony dodatkami z poźniejszych autorów, rękopismów, dowodów urzędowych. Lipsk: Wydany przez Jana Nep. Bobrowicza, T. 8 [in Polish].

Karolczak, K. (2001). Dzieduszyccy: dzieje rodu: linia poturzycko-zarzecka. Kraków: Wydawnyctwo Naukowe Akademii Pedagogicznej [in Polish].

Karolczak, K. (1998). Dzieduszyckich związki ze Lwowem. In Żaliński Henryk W. \& i Karolczak Kazimierz (Eds.). Lwów: miasto, społeczeństwo, kultura: studia z dziejów Lwowa. T. 2. Kraków: Wydawnictwo Naukowe Wyższej Szkoły Pedagogicznej [in Polish].

Lisiecka, E. \& Zdeb, K. $\quad$ (2017). Koniuszyna Wielka Koronna. Retrieved from http://przewodnicyzamosc.pl/archiwa/5528 [in Polish].

Łobieski, F. (1856). Pomnik Jerzego i Maryanny z Zamojskich Dzieduszyckich w kościołeJezuitów (Dodatek tygodniowy przy Gazecie Lwowskiej, № 37) [in Polish].

Łuszczak, G. (2010). Nauczyciele i wychowawcy szkól jezuickich we Lwowie 1608-1773. Kraków: Wydawnictwo WAM [in Polish].

Mączyński, R. (2003). Nowożytne konfesje polskie. Artystyczne fory gloryfikacji grobów świętych i błogosławionych w dawnej Rzeczypospolitej. Toruń: Wydawnictwo UMK [in Polish].

Paszenda, J. (2000). Kosciół jezuitów we Lwowie w świetle żródeł archiwalnych. Budowle jezuickie w Polsce. T. 2. Kraków [in Polish].

Sygański, Jan (1906). Święty Stanisław Kostka. Patron Lwowa. Lwów: Z drukani E. Winiarza [in Polish].

Załęski, S. (1880). O0. Jezuici we Lwowie. Lwów: czcionkami Drukarni Ludowej [in Polish].

Załęski, S. (1897). Kościół oo. jezuitów we Lwowie pod wezwaniem ss. Apostołów Piotra i Pawła. Lwów: nakładem 00. Jezuitów [in Polish].

Załęski, S. (1904). Jezuici w Polsce. Kolegia i domy założone w pierwszej dobie rzq̨dów Zygmunta III, 15881608. T. IV, Cz. 2. Kraków: Drukiem i nakładem Drukarni W. Lanczyca i sp. [in Polish]. 


\section{Oleg Druzdiev}

(Mission «Military Chaplaincy Center» Lviv Archdiocese of the UGCC, Lviv, Ukraine)

e-mail: oleg.druzdev@gmail.com

ORCID: https://orcid.org/0000-0002-2110-8948

\section{Cultural Heritage Objects of Garrison Temple of St. Apostles Peter and Paul (Jesuit Church) in Lviv: Chapel of St. Benedict}

With the opening of the former Jesuit church in December 2011, which received a new status of the city's Garrison Temple, there was a need to study its cultural heritage. Apparently, at the time when the building served as a repository of the Vasyl Stefanyk National Scientific Library of Ukraine in Lviv, access for researchers was limited. This fact can explain the lack of research in Ukrainian and the relatively small number of studies in Polish historiography.

At the same time, the process of revitalization of the temple makes important the issues of cultural and historical studies, which should primarily help in the restoration work. Considering the fact that the temple still has some elements of the chapel of St. Benedict, among which is the entrance portal and several other elements that need to be restored, the study of this sacred place becomes relevant.

It should be noted that the construction of this chapel took place in parallel with the restoration of the temple itself after the fire of 1734. Accordingly, architecturally, culturally, and religiously, the chapel became an integral part of the idea of restoring the temple itself.

The emergence of the relics of St. Benedict, which were presented by Pope Jerzy Stanisław Dzieduszycki, in Lviv Jesuit church testified to many important at that time things. First of all, that fact emphasized the status of the disciples of local Jesuits, among which was Jerzy Stanisław. In addition, the relics presented by the Pope had a certain religious status. It was believed that St. Benedict was the patron saint helping to combat diseases, and the Pope even granted permission of giving absolution on St. Benedict's Day. Correspondingly, with the appearance of the chapel with the relics of the saint, the Jesuit temple became a place of giving absolution, which raised its status.

In addition, the generous donations that followed the foundation of the chapel obviously had a positive effect on the financial situation of the Society of Jesus in Lviv. Thus, the construction of the chapel made necessary, as of the middle of the $18^{\text {th }}$ century, and positive influence on the image of Lviv Jesuits.

After the liquidation of the Society of Jesus in 1773, the popularity of the cult of St. Benedict fell. The Dzieduszycki supported the activities of the chapel, and through their efforts, the relics remained in the temple until 1946, and later they were taken to Poland.

However, taking into account the process of restoration of the temple after the Soviet period, the history of the chapel of St. Benedict is an important page of our history that needs thorough study.

Keywords: Jesuit church, Jesuits, Garrison temple, St. Benedict the Martyr, Dzieduszycki, Zamoyscy, Jabłonowscy 